\title{
Значення комплаєнтності пацієнтів у довготривалій модифікації стилю життя в процесі корекції маси тіла
}

\author{
Удк 616-021.5+616-08-039.71
}

\author{
М. Г. Аравіцька', О. Б. Лазарєва²
}

1 Прикарпатський національний університет імені Василя Стефаника, ІваноФранківськ, Україна

Національний університет фізичного виховання і спорту України, Київ, Україна

Резюме. Мета. Визначити значення реабілітаційної комплаєнтності пацієнтів у довготривалій модифікації стилю життя в процесі корекції маси тіла в рамках програми фізичної терапії. Методи. Обстежено 288 осіб другого зрілого віку з аліментарно-екзогенним ожирінням IIII ступеня. За результатами визначення реабілітаційного комплаєнсу їх було поділено на дві групи. Групу порівняння становили особи з низьким рівнем комплаєнсу, які були інформовані про ризики ожиріння та принципи зменшення маси тіла. Основну групу становили особи з високим рівнем комплаєнсу, які проходили річну програму корекції із застосуванням заходів для підтримки комплаєнсу, модифікації харчування, збільшення фізичної активності, лімфодренажу, психокорекції. Контрольну групу становили 60 осіб з нормальною масою тіла. За допомогою анкетування визначали поширеність модифікованих факторів ризику виникнення ожиріння у стилі життя. Після впровадження реабілітаційної програми повторно визначали їх поширеність; ефективність програми визначали за динамікою індексу маси тіла. Результати. Початкове анкетування показало значну поширеність модифікованих етіологічних факторів ожиріння. У пацієнтів основної групи після річного періоду спостереження за всіма запитаннями анкети визначалось значне зменшення поширеності факторів ризику ожиріння. На фоні застосування програми реабілітації із використанням заходів для утримання комплаєнсу на високому рівні досягнуто статистично значущого покращення індексу маси тіла. Висновок. Високий рівень комплаєнсу сприяє тривалій модифікації стилю життя хворих ожирінням, виконанню ними наданих рекомендацій i, як наслідок, значному зменшенню маси тіла. Низький рівень комплаєнсу супроводжується невиконанням рекомендацій щодо модифікації стилю життя та відсутністю зменшення маси тіла.

Ключові слова: фізична терапія, реабілітація, ожиріння, модифікація стилю життя.

The importance of patient compliance in long-term lifestyle modification in the process of body weight correction

M. G. Aravitska', O. B. Lazareva²

1V. Stefanyk Precarpathian National University, Ivano-Frankivsk, Ukraine ${ }^{2}$ National University of Physical Education and Sport of Ukraine, Kyiv, Ukraine

Abstract. Objective. To determine the importance of rehabilitation compliance of patients in longterm lifestyle modification in the process of body weight correction as part of a physical therapy program. Methods. 288 people of the second mature age with alimentary-exogenous obesity of the I-III degree were examined. According to the results of determining rehabilitation compliance, they were divided into two parts. The comparison group consisted of individuals with a low level of compliance, informed about the risks of obesity and the principles of weight loss. The main group consisted of individuals with a high level of compliance who underwent a one-year correction program using measures to support compliance, nutrition modification, increased physical activity, lymphatic drainage, and psychocorrection. The control group consisted of 60 people with normal body weight. The questionnaire was used to determine the prevalence of modified lifestyle risk factors for obesity. After the introduction of the rehabilitation program, their prevalence was redetermined; the effectiveness of the program was determined by the dynamics of the body mass index. Results. The initial questionnaire showed the widespread prevalence of modified etiological factors of obesity. In patients of the main group, after a follow-up period for all questions of the 
questionnaire, a significant decrease in the prevalence of risk factors for obesity was determined. Against the background of the use of the rehabilitation program using measures to maintain compliance at a high level, a statistically significant improvement in body mass index was achieved. Conclusion. A high level of compliance contributes to the long-term modification of the lifestyle of obese patients, their fulfillment of the recommendations provided and, as a result, a significant reduction in body weight. A low level of compliance is accompanied by non-compliance with recommendations for lifestyle modification and a lack of weight loss.

Key words: physical therapy, rehabilitation, obesity, lifestyle modification.

Постановка проблеми. Ожиріння в світі стало епідемією, тому все частіше актуалізується як серйозна проблема сучасної охорони здоров'я. Численні епідеміологічні дослідження показали, що воно пов'язане зі збільшеними ризиками захворюваності, непрацездатності та смертності [7, $10,19]$. Встановлено, що ожиріння впливає на смертність майже так само, як куріння [18].

Швидке зростання епідемії ожиріння пов'язане зі збільшенням доступності продуктів харчування в усьому світі та зменшенням можливостей для рухової активності у зв'язку із більш нерухомим характером багатьох видів діяльності, зі змінами в способах пересування та зі зростаючою урбанізацією. Продукти харчування ніколи не були настільки доступними, а до категорії найдешевшої відноситься їжа з високим вмістом жирів і цукру, але зі зниженим вмістом вітамінів, мінеральних речовин та інших поживних мікроелементів. Рівень рухової активності принаймні двох третин дорослого населення країн Європи є недостатньо високим для підтримки і поліпшення здоров'я. Це відбулося внаслідок переходу з енергоємних видів діяльності, таких, як сільське господарство, до діяльності в сорері обслуговування; паралельного скорочення рівня рухової активності в кожному виді діяльності; змін у бік скорочення витрати енергії під час вибору способу пересування і проведення дозвілля. Отже, стиль життя сучасного урбаністичного суспільства, в якому спостерігається тенденція до зайвого споживання харчових продуктів і сидячого способу життя, можна охарактеризувати як такий, що сприяє ожирінню [4, 15, 19].

Маса тіла залежить головним чином від раціону харчування, проте методологічні труднощі, пов'язані з точним визначенням характеру харчових звичок, ускладнюють аналіз специфічних детермінантів ожиріння, пов'язаних зі споживанням їжі. Надлишкова маса тіла виникає у тому випадку, якщо кількість спожитої енергії протягом тривалого часу перевищує ї̈ витрати, переважно за рахунок раціонів харчування з високою енергетичною щільністю (з високим вмістом жиру або вуглеводів та з низьким вмістом клітковини), на- поїв із високим вмістом цукру або їжі великими порціями $[5,13,17,19]$.

Підвищений індекс маси тіла (IMT) $€$ істотним чинником ризику щодо таких хронічних неіндекційних захворювань, як серцево-судинні, цукровий діабет, патологія кістково-м'язової системи, деякі онкологічні захворювання (внутрішньоматкові, молочної залози, товстої кишки) тощо $[17,19]$.

В основі сучасного підходу до зменшення маси тіла лежить визнання хронічного характеру ожиріння. Найбільший ефект підтримання досягнутої втрати ваги спостерігається у пацієнтів у разі дотримання таких умов: самоконтроль маси тіла; дотримання низькожирової дієти; щоденна рухова активність не менше 60 хв; мінімальна тривалість «сидячого» проведення часу; переважне споживання їжі в домашніх умовах. Небажаними $€$ методи, що спричиняють зниження маси тіла $>5$ кг у місяць (оскільки швидке зниження рівня лептину через різке схуднення призведе до компенсаторного збільшення прийому їжі і повторного набирання ваги). Тому виправданими $\epsilon$ довгострокові стратегії модифрікації маси тіла для запобігання рецидивам $[5,8,17]$.

Існують переконливі докази того, що низький рівень рухової активності та сидячий спосіб життя пов'язані зі збільшенням маси тіла. Сприятливий вплив на здоров'я, що надає регулярна рухова активність помірної інтенсивності, наприклад, зменшення ризику смертності від серцевосудинних захворювань, поширюється на всіх людей незалежно від їх маси тіла [17, 19].

Отже, стратегії профрілактики та корекції ожиріння відповідають рекомендаціям 3 профрілактики та лікування численних хронічних хвороб. Відповідно реабілітація хворих на ожиріння $\epsilon$ складним тривалим комплексним процесом, а метою ффізичної терапії повинно бути не тільки зменшення ваги, але й утримання досягнутого результату впродовж тривалого часу.

Мета дослідження - визначити значення реабілітаційної комплаєнтності пацієнтів у довготривалій модифікації стилю життя в процесі корекції маси тіла в рамках програми фрізичної терапії. 
Матеріали та методи дослідження. Обстежено 288 осіб другого зрілого віку (39,6 \pm 1,4 року) з аліментарно-конституціональним ожирінням (АКО), діагностованим за ІМТ: І ступінь 65 жінок, 51 чоловік; II ступінь - 64 жінки, 43 чоловіки; III ступінь - 43 жінки, 31 чоловік. За розробленою анкетою визначали наявність фракторів стилю життя, які $є$ загрозливими щодо розвитку надмірної маси тіла та АКО: надлишкове харчування, низька рухова активність, наявність стресових ситуацій, порушення сну.

За результатами визначення ступеня реабілітаційного комплаєнсу [1] пацієнтів було поділено на дві групи: порівняння (з низьким рівнем комплаєнсу, представники якої не проходили програму реабілітації для зменшення маси тіла, але були проінформовані про ризики ожиріння; ознайомлені з основними принципами гіпокалорійного харчування та рухової активності при ожирінні) - ГП1, ГП2, ГПЗ відповідно до ступеня ожиріння та IMT; та основну (з високим рівнем комплаєнсу, проходили річну розроблену програму корекції маси тіла із застосуванням модифрікації харчування, збільшення побутової та тренувальної рухової активності, лімфодренажних процедур, елементів поведінкової психокорекції, заходів для підтримання досягнутого рівня комплаєнсу) - ОГ1, ОГ2, ОГЗ відповідно до ступеня ожиріння та IMT.

Після впровадження програми фрізичної терапії проводили повторне розпитування пацієнтів щодо модифікації виявлених фракторів ризику АКО та визначали IMT.

Комісія з біоетики ДВНЗ «Прикарпатський національний університет імені Василя Стефани- ка» схвалила застосування представлених методів дослідження. Всі учасники були інформовані про цілі, організацію, методи дослідження та надали інформовану згоду щодо участі у ньому.

Робота виконана згідно з планом науководослідних робіт ДВНЗ «Прикарпатський національний університет імені Василя Стесраника» і $\epsilon$ фррагментом дослідження на тему: «Використання немедикаментозних засобів і природних фракторів для покращення фрізичного розвитку, функціональної і фрізичної підготовленості організму» (номер держреєстрації 0110U001671).

Результати дослідження. Результати анкетування хворих показали широку поширеність у них модисрікованих етіологічних фракторів ожиріння (табл. 1).

У ході аналізу особливостей стилю харчування встановлено, що для хворих АКО, порівняно з КГ, $є$ характерним порушення режиму харчування: збільшення частоти прийомів їжі, переважне харчування в другій половині дня. Також виявлено фрактори порушення збалансованості раціону: перевищення добової калорійності за рахунок переважного вживання тваринних жирів, надмірного вживання солі та солодощів; недостатнє вживання овочів та фруктів; часте вживання фраст-фруду.

Під час з'ясування шкідливих звичок було виявлено, що хворі АКО вживають значну кількість алкогольних напоїв, які також $€$ джерелом енергії; часто $є$ курцями (що більшість хворих виправдовували як метод контролю маси тіла та протистресовий засіб).

Серед пацієнтів 3 ожирінням частим було відчуття стресу та внутрішнього напруженя, яке

ТАБЛИЦЯ 1 - Зміни стилю життя осіб з АКО під впливом програми фізичної терапії

\begin{tabular}{|c|c|c|c|c|c|c|c|c|c|c|c|c|c|}
\hline \multirow{3}{*}{ Запитання анкети } & \multirow{3}{*}{$3(n=63)$} & \multicolumn{12}{|c|}{ Хворі на ожиріння, \% (кількість осіб) } \\
\hline & & \multicolumn{4}{|c|}{ І ступінь } & \multicolumn{4}{|c|}{ ІІ ступінь } & \multicolumn{4}{|c|}{ III ступінь } \\
\hline & & \multicolumn{2}{|c|}{ ГП1 (n= 60) } & \multicolumn{2}{|c|}{ ОГ1 $(n=53)$} & \multicolumn{2}{|c|}{ ГП2 ( $(n=57)$} & \multicolumn{2}{|c|}{ ОГ2 $(n=41)$} & \multicolumn{2}{|c|}{ ГП3 (n= 47) } & \multicolumn{2}{|c|}{ ОГ3 $(n=27)$} \\
\hline \multicolumn{14}{|c|}{ Стиль харчування } \\
\hline \multicolumn{14}{|l|}{$\begin{array}{l}\text { Частота основних прийомів їжі } \\
\text { на добу (без перекусів) }\end{array}$} \\
\hline один раз & 0 & $\begin{array}{c}6,67 \\
(4)\end{array}$ & $\begin{array}{c}8,33 \\
(5)\end{array}$ & $\begin{array}{c}5,66 \\
(3)\end{array}$ & 0 & $\begin{array}{c}1,75 \\
(1)\end{array}$ & 0 & 0 & 0 & 0 & 0 & 0 & 0 \\
\hline два рази & $\begin{array}{c}28,57 \\
(18)\end{array}$ & $\begin{array}{c}15,00 \\
(9)\end{array}$ & $\begin{array}{c}13,33 \\
(8)\end{array}$ & $\begin{array}{c}16,98 \\
(9)\end{array}$ & $\begin{array}{c}15,09 \\
(8)\end{array}$ & $\begin{array}{c}21,05 \\
(12)\end{array}$ & $\begin{array}{c}22,81 \\
(13)\end{array}$ & $\begin{array}{c}21,95 \\
(9)\end{array}$ & $\begin{array}{c}4,88 \\
(2)\end{array}$ & 0 & 0 & 0 & 0 \\
\hline три-чотири рази & $\begin{array}{l}71,43 \\
(45)\end{array}$ & $\begin{array}{c}56,67 \\
(34)\end{array}$ & $\begin{array}{c}58,33 \\
(35)\end{array}$ & $\begin{array}{c}56,60 \\
(30)\end{array}$ & $\begin{array}{c}84,91 \\
(45)\end{array}$ & $\begin{array}{c}43,86 \\
(25)\end{array}$ & $\begin{array}{c}40,35 \\
(23)\end{array}$ & $\begin{array}{c}41,46 \\
(17)\end{array}$ & $\begin{array}{c}95,12 \\
(39)\end{array}$ & $\begin{array}{c}31,91 \\
(15)\end{array}$ & $\begin{array}{c}61,70 \\
(29)\end{array}$ & $\begin{array}{c}33,33 \\
(9)\end{array}$ & $\begin{array}{l}100 \\
(27)\end{array}$ \\
\hline більше чотирьох разів & 0 & $\begin{array}{c}21,67 \\
(13)\end{array}$ & $\begin{array}{c}20,00 \\
(12)\end{array}$ & $\begin{array}{c}20,75 \\
(11)\end{array}$ & 0 & $\begin{array}{c}33,33 \\
(19)\end{array}$ & $\begin{array}{c}36,84 \\
(21)\end{array}$ & $\begin{array}{c}36,59 \\
(15)\end{array}$ & 0 & $\begin{array}{c}68,09 \\
(32)\end{array}$ & $\begin{array}{c}38,30 \\
(18)\end{array}$ & $\begin{array}{c}66,67 \\
(18)\end{array}$ & 0 \\
\hline \multicolumn{14}{|l|}{$\begin{array}{l}\text { Час переважного вживання їжі } \\
\text { (за калорійностю та об'ємом) }\end{array}$} \\
\hline $\begin{array}{l}\text { ранок-обід (перша половина } \\
\text { дня) }\end{array}$ & $\begin{array}{c}87,30 \\
(55)\end{array}$ & $\begin{array}{c}36,67 \\
(22)\end{array}$ & $\begin{array}{c}35,00 \\
(21)\end{array}$ & $\begin{array}{c}35,85 \\
(19)\end{array}$ & $\begin{array}{c}83,02 \\
(44)\end{array}$ & $\begin{array}{c}17,54 \\
(10)\end{array}$ & $\begin{array}{c}14,04 \\
(8)\end{array}$ & $\begin{array}{c}17,07 \\
(7)\end{array}$ & $\begin{array}{c}19,51 \\
(8)\end{array}$ & \begin{tabular}{|c|}
10,64 \\
$(5)$
\end{tabular} & $\begin{array}{c}12,77 \\
(6)\end{array}$ & $\begin{array}{c}11,11 \\
(3)\end{array}$ & $\begin{array}{c}92,59 \\
(25)\end{array}$ \\
\hline
\end{tabular}


Продовження таблиці 1

\begin{tabular}{|c|c|c|c|c|c|c|c|c|c|c|c|c|c|}
\hline \multirow{4}{*}{$\begin{array}{l}\text { Запитання анкети } \\
\begin{array}{l}\text { обід - вечеря (друга } \\
\text { половина дня) }\end{array} \\
\end{array}$} & \multirow{4}{*}{$\begin{array}{c}3(n=63) \\
\\
12,70 \\
(8)\end{array}$} & \multicolumn{12}{|c|}{ Хворі на ожиріння, \% (кількість осіб) } \\
\hline & & \multicolumn{4}{|c|}{ І ступінь } & \multicolumn{4}{|c|}{ ІІ ступінь } & \multicolumn{4}{|c|}{ III ступінь } \\
\hline & & \multicolumn{2}{|c|}{ ГП1 (n = 60) } & \multicolumn{2}{|c|}{ ОГ1 $(n=53)$} & \multicolumn{2}{|c|}{ ГП2 (n = 57) } & \multicolumn{2}{|c|}{ ОГ2 $(n=41)$} & \multicolumn{2}{|c|}{ ГП3 $(n=47)$} & \multicolumn{2}{|c|}{ ОГ3 $(n=27)$} \\
\hline & & $\begin{array}{c}63,33 \\
(38)\end{array}$ & $\begin{array}{c}65,00 \\
(39)\end{array}$ & $\begin{array}{c}64,15 \\
(34)\end{array}$ & $\begin{array}{c}16,98 \\
(9)\end{array}$ & $\begin{array}{c}82,46 \\
(47)\end{array}$ & $\begin{array}{c}85,96 \\
(49)\end{array}$ & $\begin{array}{c}82,93 \\
(34)\end{array}$ & $\begin{array}{c}80,49 \\
(33)\end{array}$ & $\begin{array}{c}89,36 \\
(42)\end{array}$ & $\begin{array}{c}87,23 \\
(41)\end{array}$ & $\begin{array}{c}88,89 \\
(24)\end{array}$ & $\begin{array}{c}7,41 \\
(2)\end{array}$ \\
\hline \multicolumn{14}{|l|}{$\begin{array}{l}\text { Час останнього прийому їжі } \\
\text { (або перекусу) }\end{array}$} \\
\hline до 17 год & $\begin{array}{c}63,49 \\
(40)\end{array}$ & \begin{tabular}{|c|}
18,33 \\
$(11)$
\end{tabular} & $\begin{array}{c}16,67 \\
(10)\end{array}$ & \begin{tabular}{|c|}
18,87 \\
$(10)$
\end{tabular} & $\begin{array}{c}71,70 \\
(38) \\
\end{array}$ & 0 & 0 & 0 & \begin{tabular}{|c|}
26,83 \\
$(11)$
\end{tabular} & 0 & 0 & 0 & $\begin{array}{c}11,11 \\
(3)\end{array}$ \\
\hline 17-20 год & $\begin{array}{c}30,16 \\
(19)\end{array}$ & $\begin{array}{c}53,33 \\
(32)\end{array}$ & $\begin{array}{c}53,33 \\
(32)\end{array}$ & $\begin{array}{c}50,94 \\
(27)\end{array}$ & $\begin{array}{c}28,30 \\
(15)\end{array}$ & $\begin{array}{c}49,12 \\
(28)\end{array}$ & \begin{tabular}{|c|}
47,37 \\
$(27)$
\end{tabular} & $\begin{array}{c}48,78 \\
(20)\end{array}$ & $\begin{array}{c}68,29 \\
(28)\end{array}$ & $\begin{array}{c}19,15 \\
(9)\end{array}$ & $\begin{array}{c}17,02 \\
(8)\end{array}$ & $\begin{array}{c}17,86 \\
(5)\end{array}$ & $\begin{array}{c}85,19 \\
(23)\end{array}$ \\
\hline після 20 год & $\begin{array}{c}6,35 \\
(4)\end{array}$ & $\begin{array}{c}28,33 \\
(17)\end{array}$ & $\begin{array}{c}30,00 \\
(18)\end{array}$ & $\begin{array}{c}30,19 \\
(16)\end{array}$ & 0 & $\begin{array}{c}50,88 \\
(29)\end{array}$ & $\begin{array}{c}52,63 \\
(30)\end{array}$ & $\begin{array}{c}51,22 \\
(21)\end{array}$ & $\begin{array}{c}4,88 \\
(2)\end{array}$ & $\begin{array}{c}80,85 \\
(38)\end{array}$ & $\begin{array}{c}82,98 \\
(39)\end{array}$ & $\begin{array}{c}81,48 \\
(22)\end{array}$ & $\begin{array}{c}3,70 \\
(1)\end{array}$ \\
\hline \multicolumn{14}{|l|}{$\begin{array}{l}\text { Вживання жирів для } \\
\text { приготування їжі }\end{array}$} \\
\hline переважно тваринні & $\begin{array}{c}7,94 \\
(5)\end{array}$ & $\begin{array}{c}45,00 \\
(27)\end{array}$ & $\begin{array}{c}48,33 \\
(29)\end{array}$ & \begin{tabular}{|c|}
43,40 \\
$(23)$
\end{tabular} & $\begin{array}{c}5,66 \\
(3)\end{array}$ & $\begin{array}{c}57,89 \\
(33)\end{array}$ & \begin{tabular}{|c|}
61,40 \\
$(35)$
\end{tabular} & \begin{tabular}{|c|}
53,66 \\
$(22)$ \\
\end{tabular} & $\begin{array}{c}9,76 \\
(4)\end{array}$ & \begin{tabular}{|c|}
78,72 \\
$(37)$
\end{tabular} & \begin{tabular}{|c|}
82,98 \\
$(39)$
\end{tabular} & \begin{tabular}{|c|}
77,78 \\
$(21)$
\end{tabular} & $\begin{array}{c}18,52 \\
(5)\end{array}$ \\
\hline переважно рослинні & $\begin{array}{c}57,14 \\
(36)\end{array}$ & $\begin{array}{c}16,67 \\
(10)\end{array}$ & $\begin{array}{c}15,00 \\
(9)\end{array}$ & $\begin{array}{c}18,87 \\
(10)\end{array}$ & $\begin{array}{c}64,15 \\
(34)\end{array}$ & $\begin{array}{c}12,28 \\
(7)\end{array}$ & $\begin{array}{c}10,53 \\
(6)\end{array}$ & $\begin{array}{c}12,20 \\
(5)\end{array}$ & $\begin{array}{c}78,05 \\
(32)\end{array}$ & 0 & 0 & 0 & $\begin{array}{c}77,78 \\
(21)\end{array}$ \\
\hline без жирів & $\begin{array}{c}19,05 \\
(12)\end{array}$ & 0 & 0 & 0 & $\begin{array}{c}11,32 \\
(6)\end{array}$ & 0 & 0 & 0 & 0 & 0 & 0 & 0 & 0 \\
\hline $\begin{array}{l}\text { будь-які (суміш/не обираю } \\
\text { спеціально) }\end{array}$ & $\begin{array}{c}15,87 \\
(10)\end{array}$ & $\begin{array}{c}38,33 \\
(23)\end{array}$ & $\begin{array}{c}36,67 \\
(22)\end{array}$ & $\begin{array}{c}37,74 \\
(20)\end{array}$ & $\begin{array}{c}18,87 \\
(10)\end{array}$ & $\begin{array}{c}29,82 \\
(17)\end{array}$ & $\begin{array}{c}28,07 \\
(16)\end{array}$ & $\begin{array}{c}34,15 \\
(14)\end{array}$ & $\begin{array}{c}12,20 \\
(5)\end{array}$ & $\begin{array}{c}21,28 \\
(10)\end{array}$ & $\begin{array}{c}17,02 \\
(8)\end{array}$ & $\begin{array}{c}22,22 \\
(6)\end{array}$ & $\begin{array}{c}3,70 \\
(1)\end{array}$ \\
\hline \multicolumn{14}{|l|}{$\begin{array}{l}\text { Надмірне вживання солі } \\
\text { (понад } 5 \text { г на добу) }\end{array}$} \\
\hline так & $\begin{array}{c}12,70 \\
(8)\end{array}$ & \begin{tabular}{|c|}
36,67 \\
$(22)$
\end{tabular} & $\begin{array}{c}41,67 \\
(25)\end{array}$ & \begin{tabular}{|c|}
37,74 \\
$(20)$
\end{tabular} & $\begin{array}{c}15,09 \\
(8)\end{array}$ & $\begin{array}{c}61,40 \\
(35)\end{array}$ & \begin{tabular}{|c|}
63,16 \\
$(36)$
\end{tabular} & \begin{tabular}{|c|}
60,98 \\
$(25)$
\end{tabular} & \begin{tabular}{|c|}
24,39 \\
$(10)$
\end{tabular} & \begin{tabular}{|c|}
85,11 \\
$(40)$
\end{tabular} & $\begin{array}{c}89,36 \\
(42)\end{array}$ & $\begin{array}{c}85,71 \\
(24)\end{array}$ & $\begin{array}{c}18,52 \\
(5)\end{array}$ \\
\hline $\mathrm{Hi}$ & $\begin{array}{c}87,30 \\
(55)\end{array}$ & \begin{tabular}{|c|}
63,33 \\
$(38)$
\end{tabular} & $\begin{array}{c}58,33 \\
(35)\end{array}$ & $\begin{array}{c}62,26 \\
(33)\end{array}$ & $\begin{array}{c}84,91 \\
(45)\end{array}$ & $\begin{array}{c}38,60 \\
(22)\end{array}$ & \begin{tabular}{|c|}
36,84 \\
$(21)$
\end{tabular} & $\begin{array}{c}39,02 \\
(16)\end{array}$ & $\begin{array}{c}75,61 \\
(31)\end{array}$ & $\begin{array}{c}14,89 \\
(7)\end{array}$ & $\begin{array}{c}10,64 \\
(5)\end{array}$ & $\begin{array}{c}10,71 \\
(3)\end{array}$ & $\begin{array}{c}81,48 \\
(22)\end{array}$ \\
\hline \multicolumn{14}{|l|}{$\begin{array}{l}\text { Вживання свіжих овочів та } \\
\text { фруктів }\end{array}$} \\
\hline один-два рази на тиждень & 0 & $\begin{array}{c}15,00 \\
(9)\end{array}$ & $\begin{array}{c}13,33 \\
(8)\end{array}$ & \begin{tabular}{|c|}
16,98 \\
$(9)$
\end{tabular} & 0 & $\begin{array}{c}26,32 \\
(15)\end{array}$ & \begin{tabular}{|c|}
24,56 \\
$(14)$
\end{tabular} & \begin{tabular}{|c|}
26,83 \\
$(11)$
\end{tabular} & 0 & \begin{tabular}{|c|}
31,91 \\
$(15)$
\end{tabular} & \begin{tabular}{|c|}
34,04 \\
$(16)$
\end{tabular} & $\begin{array}{c}29,63 \\
(8)\end{array}$ & 0 \\
\hline декілька разів на тиждень & $\begin{array}{c}68,25 \\
(43)\end{array}$ & $\begin{array}{c}68,33 \\
(41)\end{array}$ & $\begin{array}{c}71,67 \\
(43)\end{array}$ & $\begin{array}{c}67,92 \\
(36)\end{array}$ & $\begin{array}{c}62,26 \\
(33)\end{array}$ & $\begin{array}{c}64,91 \\
(37)\end{array}$ & $\begin{array}{c}68,42 \\
(39)\end{array}$ & $\begin{array}{c}63,41 \\
(26)\end{array}$ & $\begin{array}{c}60,98 \\
(25)\end{array}$ & $\begin{array}{c}68,09 \\
(32)\end{array}$ & $\begin{array}{c}65,96 \\
(31)\end{array}$ & $\begin{array}{c}70,37 \\
(19)\end{array}$ & $\begin{array}{c}51,85 \\
(14)\end{array}$ \\
\hline щодня & $\begin{array}{c}31,75 \\
(20)\end{array}$ & $\begin{array}{c}16,67 \\
(10)\end{array}$ & $\begin{array}{c}15,00 \\
(9)\end{array}$ & $\begin{array}{c}15,09 \\
(8)\end{array}$ & $\begin{array}{c}37,74 \\
(20)\end{array}$ & $\begin{array}{c}8,77 \\
(5)\end{array}$ & \begin{tabular}{c|}
7,02 \\
$(4)$
\end{tabular} & $\begin{array}{c}9,76 \\
(4)\end{array}$ & $\begin{array}{c}39,02 \\
(16)\end{array}$ & 0 & 0 & 0 & $\begin{array}{c}48,15 \\
(13)\end{array}$ \\
\hline \multicolumn{14}{|l|}{$\begin{array}{l}\text { Частота вживання солодощів } \\
\text { (крім цукру) }\end{array}$} \\
\hline щодня & $\begin{array}{c}6,35 \\
(4)\end{array}$ & \begin{tabular}{|c|}
23,33 \\
$(14)$
\end{tabular} & $\begin{array}{c}26,67 \\
(16)\end{array}$ & \begin{tabular}{|c|}
28,30 \\
$(15)$
\end{tabular} & & $\begin{array}{c}61,40 \\
(35)\end{array}$ & \begin{tabular}{|c|}
64,91 \\
$(37)$
\end{tabular} & \begin{tabular}{|c|}
60,98 \\
$(25)$
\end{tabular} & & \begin{tabular}{|c|}
89,36 \\
$(42)$
\end{tabular} & $\begin{array}{c}95,74 \\
(45)\end{array}$ & $\begin{array}{c}92,59 \\
(25)\end{array}$ & \\
\hline декілька разів на тиждень & $\begin{array}{c}71,43 \\
(45)\end{array}$ & $\begin{array}{c}76,67 \\
(46)\end{array}$ & $\begin{array}{c}73,33 \\
(44)\end{array}$ & $\begin{array}{c}71,70 \\
(38)\end{array}$ & $\begin{array}{c}83,02 \\
(44)\end{array}$ & $\begin{array}{c}38,60 \\
(22)\end{array}$ & $\begin{array}{c}35,09 \\
(20)\end{array}$ & $\begin{array}{c}39,02 \\
(16)\end{array}$ & $\begin{array}{c}92,68 \\
(38)\end{array}$ & $\begin{array}{c}10,64 \\
(5)\end{array}$ & $\begin{array}{c}4,26 \\
(2)\end{array}$ & $\begin{array}{c}7,41 \\
(2)\end{array}$ & $\begin{array}{c}96,30 \\
(26)\end{array}$ \\
\hline не вживаю & $\begin{array}{c}22,22 \\
(14)\end{array}$ & 0 & 0 & 0 & $\begin{array}{c}16,98 \\
(9)\end{array}$ & 0 & 0 & 0 & \begin{tabular}{c|}
7,32 \\
$(3)$
\end{tabular} & 0 & 0 & 0 & $\begin{array}{c}3,70 \\
(1)\end{array}$ \\
\hline \multicolumn{14}{|l|}{$\begin{array}{l}\text { Кількість чайних ложок цукру } \\
\text { на добу }\end{array}$} \\
\hline не вживаю & $\begin{array}{c}14,29 \\
(9)\end{array}$ & 0 & 0 & 0 & $\begin{array}{c}15,09 \\
(8)\end{array}$ & 0 & 0 & 0 & $\begin{array}{c}9,76 \\
(4)\end{array}$ & 0 & 0 & 0 & $\begin{array}{c}7,41 \\
(2)\end{array}$ \\
\hline вживаю цукрозамінник & $\begin{array}{c}15,87 \\
(10)\end{array}$ & $\begin{array}{c}8,33 \\
(5)\end{array}$ & $\begin{array}{c}6,67 \\
(4)\end{array}$ & \begin{tabular}{c|}
9,43 \\
$(5)$
\end{tabular} & $\begin{array}{c}11,32 \\
(6)\end{array}$ & $\begin{array}{c}5,26 \\
(3)\end{array}$ & \begin{tabular}{c|}
5,26 \\
$(3)$
\end{tabular} & $\begin{array}{c}4,88 \\
(2)\end{array}$ & $\begin{array}{c}17,07 \\
(7)\end{array}$ & $\begin{array}{c}14,89 \\
(7)\end{array}$ & \begin{tabular}{|c|}
6,38 \\
$(3)$
\end{tabular} & $\begin{array}{c}11,11 \\
(3)\end{array}$ & $\begin{array}{c}14,81 \\
(4)\end{array}$ \\
\hline до 6 & $\begin{array}{c}63,49 \\
(40)\end{array}$ & $\begin{array}{c}25,00 \\
(15)\end{array}$ & $\begin{array}{c}21,67 \\
(13)\end{array}$ & $\begin{array}{c}24,53 \\
(13)\end{array}$ & $\begin{array}{c}69,81 \\
(37)\end{array}$ & $\begin{array}{c}19,30 \\
(11)\end{array}$ & $\begin{array}{c}15,79 \\
(9)\end{array}$ & $\begin{array}{c}17,07 \\
(7)\end{array}$ & $\begin{array}{c}60,98 \\
(25)\end{array}$ & $\begin{array}{c}10,64 \\
(5)\end{array}$ & $\begin{array}{c}10,64 \\
(5)\end{array}$ & \begin{tabular}{|c|}
7,41 \\
$(2)$
\end{tabular} & $\begin{array}{c}77,78 \\
(21)\end{array}$ \\
\hline більше 6 & $\begin{array}{c}6,35 \\
(4)\end{array}$ & $\begin{array}{c}66,67 \\
(40)\end{array}$ & $\begin{array}{c}71,67 \\
(43)\end{array}$ & $\begin{array}{c}66,04 \\
(35)\end{array}$ & $\begin{array}{c}3,77 \\
(2)\end{array}$ & $\begin{array}{c}75,44 \\
(43)\end{array}$ & $\begin{array}{c}78,95 \\
(45)\end{array}$ & $\begin{array}{c}78,05 \\
(32)\end{array}$ & $\begin{array}{c}12,20 \\
(5)\end{array}$ & $\begin{array}{c}74,47 \\
(35)\end{array}$ & $\begin{array}{c}82,98 \\
(39)\end{array}$ & $\begin{array}{c}81,48 \\
(22)\end{array}$ & 0 \\
\hline \multicolumn{14}{|l|}{ Частота вживання фастфуду } \\
\hline щодня & 0 & \begin{tabular}{|c|}
30,00 \\
$(18)$
\end{tabular} & $\begin{array}{c}33,33 \\
(20)\end{array}$ & \begin{tabular}{|c|}
28,30 \\
$(15)$
\end{tabular} & 0 & $\begin{array}{c}54,39 \\
(31)\end{array}$ & \begin{tabular}{|c|}
57,89 \\
$(33)$
\end{tabular} & \begin{tabular}{|c|}
56,10 \\
$(23)$
\end{tabular} & 0 & \begin{tabular}{|c|}
68,09 \\
$(32)$
\end{tabular} & \begin{tabular}{|c|}
74,47 \\
$(35)$
\end{tabular} & $\begin{array}{c}70,37 \\
(19)\end{array}$ & 0 \\
\hline декілька разів на тиждень & $\begin{array}{c}76,19 \\
(48)\end{array}$ & $\begin{array}{c}61,67 \\
(37)\end{array}$ & $\begin{array}{c}61,67 \\
(37)\end{array}$ & $\begin{array}{c}64,15 \\
(34)\end{array}$ & $\begin{array}{c}37,74 \\
(20)\end{array}$ & $\begin{array}{c}45,61 \\
(26)\end{array}$ & $\begin{array}{c}42,11 \\
(24)\end{array}$ & $\begin{array}{c}43,90 \\
(18)\end{array}$ & $\begin{array}{c}39,02 \\
(16)\end{array}$ & $\begin{array}{c}31,91 \\
(15)\end{array}$ & $\begin{array}{c}25,53 \\
(12)\end{array}$ & $\begin{array}{c}29,63 \\
(8)\end{array}$ & $\begin{array}{c}37,04 \\
(10)\end{array}$ \\
\hline
\end{tabular}


Продовження таблиці 1

\begin{tabular}{|c|c|c|c|c|c|c|c|c|c|c|c|c|c|}
\hline \multirow{4}{*}{\begin{tabular}{|l} 
Запитання анкети \\
не вживаю
\end{tabular}} & \multirow{4}{*}{$\begin{array}{c}3(n=63) \\
23,81 \\
(15) \\
\end{array}$} & \multicolumn{12}{|c|}{ Хворі на ожиріння, \% (кількість осіб) } \\
\hline & & \multicolumn{4}{|c|}{ І ступінь } & \multicolumn{4}{|c|}{ ІІ ступінь } & \multicolumn{4}{|c|}{ III ступінь } \\
\hline & & \multicolumn{2}{|c|}{ ГП1 $(n=60)$} & \multicolumn{2}{|c|}{ ОГ1 $(n=53)$} & \multicolumn{2}{|c|}{ ГП2 (n = 57) } & \multicolumn{2}{|c|}{ ОГ2 $(n=41)$} & \multicolumn{2}{|c|}{ ГПЗ $(n=47)$} & \multicolumn{2}{|c|}{ ОГЗ $(n=27)$} \\
\hline & & $\begin{array}{c}8,33 \\
(5)\end{array}$ & $\begin{array}{l}5,00 \\
3()\end{array}$ & $\begin{array}{c}7,55 \\
(4)\end{array}$ & $\begin{array}{c}62,26 \\
(33) \\
\end{array}$ & 0 & 0 & 0 & $\begin{array}{c}60,98 \\
(25) \\
\end{array}$ & 0 & 0 & 0 & $\begin{array}{c}62,96 \\
(17)\end{array}$ \\
\hline \multicolumn{14}{|c|}{ Рухова активність } \\
\hline Тільки побутова & $\begin{array}{l}15,87 \\
(10)\end{array}$ & $\begin{array}{c}56,67 \\
(34)\end{array}$ & $\begin{array}{c}60,00 \\
(36)\end{array}$ & $\begin{array}{c}56,60 \\
(30)\end{array}$ & 0 & $\begin{array}{c}77,19 \\
(44)\end{array}$ & $\begin{array}{c}82,46 \\
(47)\end{array}$ & \begin{tabular}{|c|}
78,05 \\
$(32)$
\end{tabular} & 0 & $\begin{array}{c}93,62 \\
(44)\end{array}$ & $\begin{array}{c}97,87 \\
(46)\end{array}$ & \begin{tabular}{|c|}
92,59 \\
$(25)$
\end{tabular} & 0 \\
\hline $\begin{array}{l}\text { Побутова та несистематична } \\
\text { тренувальна }\end{array}$ & $\begin{array}{c}23,81 \\
(15)\end{array}$ & $\begin{array}{c}33,33 \\
(20)\end{array}$ & $\begin{array}{c}35,00 \\
(21)\end{array}$ & $\begin{array}{c}33,96 \\
(18)\end{array}$ & $\begin{array}{c}13,21 \\
(7)\end{array}$ & $\begin{array}{c}22,81 \\
(13)\end{array}$ & $\begin{array}{c}17,54 \\
(10)\end{array}$ & $\begin{array}{c}21,95 \\
(9)\end{array}$ & $\begin{array}{c}12,20 \\
(5)\end{array}$ & $\begin{array}{c}6,38 \\
(3)\end{array}$ & $\begin{array}{c}2,13 \\
(1)\end{array}$ & \begin{tabular}{c|}
7,41 \\
$(2)$
\end{tabular} & $\begin{array}{c}7,41 \\
(2)\end{array}$ \\
\hline $\begin{array}{l}\text { Побутова та систематична } \\
\text { тренувальна }\end{array}$ & $\begin{array}{c}60,32 \\
(38)\end{array}$ & $\begin{array}{c}10,00 \\
(6)\end{array}$ & $\begin{array}{c}5,00 \\
(3)\end{array}$ & $\begin{array}{c}9,43 \\
(5) \\
\end{array}$ & $\begin{array}{c}86,79 \\
(46) \\
\end{array}$ & 0 & 0 & 0 & $\begin{array}{c}87,80 \\
(36) \\
\end{array}$ & 0 & 0 & 0 & \begin{tabular}{|c|c}
92,59 \\
$(25)$
\end{tabular} \\
\hline \multicolumn{14}{|c|}{ Шкідливі звички } \\
\hline \multicolumn{14}{|l|}{$\begin{array}{l}\text { Частота вживання алкогольних } \\
\text { напоїв (будь-якої міцності) }\end{array}$} \\
\hline не вживаю взагалі & $\begin{array}{c}15,87 \\
(10)\end{array}$ & $\begin{array}{c}5,00 \\
(3)\end{array}$ & $\begin{array}{c}3,33 \\
(2)\end{array}$ & $\begin{array}{c}3,77 \\
(2)\end{array}$ & $\begin{array}{c}13,21 \\
() 7 \\
\end{array}$ & $\begin{array}{c}3,51 \\
(2)\end{array}$ & $\begin{array}{c}1,75 \\
(1)\end{array}$ & $\begin{array}{c}2,44 \\
(1)\end{array}$ & $\begin{array}{c}12,20 \\
(5)\end{array}$ & 0 & 0 & 0 & $\begin{array}{c}3,70 \\
(1)\end{array}$ \\
\hline рідше 1 разу на тиждень & $\begin{array}{c}77,78 \\
(49)\end{array}$ & $\begin{array}{c}66,67 \\
(40)\end{array}$ & $\begin{array}{c}65,00 \\
(39)\end{array}$ & $\begin{array}{c}69,81 \\
(37)\end{array}$ & $\begin{array}{c}84,91 \\
(45)\end{array}$ & $\begin{array}{c}56,14 \\
(32)\end{array}$ & $\begin{array}{c}52,63 \\
(30)\end{array}$ & $\begin{array}{c}56,10 \\
(23)\end{array}$ & $\begin{array}{c}85,37 \\
(35)\end{array}$ & $\begin{array}{c}31,91 \\
15()\end{array}$ & \begin{tabular}{|c|}
23,40 \\
$(11)$
\end{tabular} & $\begin{array}{c}29,63 \\
(8)\end{array}$ & $\begin{array}{c}92,59 \\
(25)\end{array}$ \\
\hline декілька разів на тиждень & $\begin{array}{c}6,35 \\
(4)\end{array}$ & $\begin{array}{c}28,33 \\
(17)\end{array}$ & \begin{tabular}{|c|}
31,67 \\
$(19)$
\end{tabular} & $\begin{array}{c}26,42 \\
(14)\end{array}$ & $\begin{array}{c}1,89 \\
(1) \\
\end{array}$ & $\begin{array}{c}40,35 \\
(23)\end{array}$ & $\begin{array}{c}45,61 \\
(26) \\
\end{array}$ & $\begin{array}{c}41,46 \\
(17) \\
\end{array}$ & $\begin{array}{c}2,44 \\
(1) \\
\end{array}$ & $\begin{array}{c}65,96 \\
(31)\end{array}$ & $\begin{array}{c}72,34 \\
(34)\end{array}$ & $\begin{array}{c}66,67 \\
(18)\end{array}$ & $\begin{array}{c}3,70 \\
(1)\end{array}$ \\
\hline щодня & 0 & 0 & 0 & 0 & 0 & 0 & 0 & 0 & 0 & $\begin{array}{c}2,13 \\
(1)\end{array}$ & \begin{tabular}{|c}
4,26 \\
$(2)$
\end{tabular} & $\begin{array}{c}3,70 \\
(1)\end{array}$ & 0 \\
\hline \multicolumn{14}{|l|}{ Куріння в даний момент } \\
\hline так & $\begin{array}{c}15,87 \\
(10)\end{array}$ & \begin{tabular}{|c|}
36,67 \\
$(22)$
\end{tabular} & \begin{tabular}{|c|}
36,67 \\
22()
\end{tabular} & \begin{tabular}{|c|}
37,74 \\
$(20)$
\end{tabular} & \begin{tabular}{|c|}
30,19 \\
$(16)$
\end{tabular} & \begin{tabular}{|c|}
38,60 \\
$(22)$
\end{tabular} & \begin{tabular}{|c|}
38,60 \\
$(22)$
\end{tabular} & \begin{tabular}{|c}
39,02 \\
$(16)$
\end{tabular} & \begin{tabular}{|c|}
31,71 \\
$(13)$
\end{tabular} & $\begin{array}{c}36,17 \\
(17)\end{array}$ & $\begin{array}{c}34,04 \\
(16)\end{array}$ & $\begin{array}{c}33,33 \\
(9)\end{array}$ & \begin{tabular}{|c}
14,81 \\
$(4)$
\end{tabular} \\
\hline $\mathrm{Hi}$ & $\begin{array}{c}84,13 \\
(53) \\
\end{array}$ & $\begin{array}{c}63,33 \\
(38) \\
\end{array}$ & \begin{tabular}{|c}
63,33 \\
$(38)$ \\
\end{tabular} & \begin{tabular}{|c|}
62,26 \\
$(33)$
\end{tabular} & $\begin{array}{c}69,81 \\
(37) \\
\end{array}$ & $\begin{array}{c}61,40 \\
(35)\end{array}$ & \begin{tabular}{|c|}
61,40 \\
$(35)$ \\
\end{tabular} & $\begin{array}{c}60,98 \\
(25)\end{array}$ & $\begin{array}{c}68,29 \\
(28)\end{array}$ & $\begin{array}{c}63,83 \\
(30)\end{array}$ & \begin{tabular}{|c|}
65,96 \\
$(31)$ \\
\end{tabular} & \begin{tabular}{|c|}
66,67 \\
$(18)$
\end{tabular} & $\begin{array}{c}85,19 \\
(23)\end{array}$ \\
\hline \multicolumn{14}{|c|}{ Стрес } \\
\hline \multicolumn{14}{|l|}{$\begin{array}{l}\text { Відчуття внутрішнього } \\
\text { напруження та неспокою }\end{array}$} \\
\hline відсутнє & $\begin{array}{c}34,92 \\
(22)\end{array}$ & $\begin{array}{c}15,00 \\
(9)\end{array}$ & $\begin{array}{c}13,33 \\
(8)\end{array}$ & $\begin{array}{c}16,98 \\
(9)\end{array}$ & \begin{tabular}{|c|}
28,30 \\
$(15)$
\end{tabular} & 0 & 0 & 0 & $\begin{array}{c}24,39 \\
(10)\end{array}$ & 0 & 0 & 0 & \begin{tabular}{|c}
18,52 \\
$(5)$
\end{tabular} \\
\hline періодично & $\begin{array}{c}60,32 \\
(38)\end{array}$ & $\begin{array}{c}60,00 \\
(36)\end{array}$ & $\begin{array}{c}58,33 \\
(35)\end{array}$ & $\begin{array}{c}58,49 \\
(31)\end{array}$ & $\begin{array}{c}64,15 \\
(34) \\
\end{array}$ & $\begin{array}{c}61,40 \\
(35)\end{array}$ & $\begin{array}{c}59,65 \\
(34)\end{array}$ & $\begin{array}{c}60,98 \\
(25)\end{array}$ & $\begin{array}{c}60,98 \\
(25)\end{array}$ & $\begin{array}{c}53,19 \\
(25)\end{array}$ & $\begin{array}{c}51,06 \\
(24)\end{array}$ & $\begin{array}{c}55,56 \\
(15)\end{array}$ & $\begin{array}{c}70,37 \\
(19)\end{array}$ \\
\hline постійно & $\begin{array}{l}4,76 \\
(3)\end{array}$ & $\begin{array}{c}25,00 \\
(15)\end{array}$ & \begin{tabular}{|c|}
28,33 \\
$(17)$
\end{tabular} & $\begin{array}{c}24,53 \\
(13)\end{array}$ & $\begin{array}{c}7,55 \\
(4)\end{array}$ & $\begin{array}{c}38,60 \\
(22)\end{array}$ & $\begin{array}{c}40,35 \\
(23)\end{array}$ & $\begin{array}{c}39,02 \\
(16)\end{array}$ & $\begin{array}{c}14,63 \\
(6)\end{array}$ & $\begin{array}{c}46,81 \\
(22)\end{array}$ & $\begin{array}{c}48,94 \\
(23)\end{array}$ & $\begin{array}{c}44,44 \\
(12)\end{array}$ & $\begin{array}{c}11,11 \\
(3)\end{array}$ \\
\hline \multicolumn{14}{|l|}{$\begin{array}{l}\text { «Заїдання» стресової ситуації } \\
\text { (\% тих, хто відчуває стрес) }\end{array}$} \\
\hline так & $\begin{array}{c}12,20 \\
(5)\end{array}$ & $\begin{array}{c}60,78 \\
(31) \\
\end{array}$ & \begin{tabular}{|c|}
61,54 \\
$(32)$ \\
\end{tabular} & \begin{tabular}{|c|}
59,09 \\
$(26)$
\end{tabular} & \begin{tabular}{|c|}
$\begin{array}{c}13,16 \\
(5)\end{array}$ \\
\end{tabular} & \begin{tabular}{|c|}
68,42 \\
$(39)$ \\
\end{tabular} & \begin{tabular}{|c|}
71,93 \\
$(41)$ \\
\end{tabular} & $\begin{array}{c}70,73 \\
(29)\end{array}$ & $\begin{array}{c}19,35 \\
(6) \\
\end{array}$ & $\begin{array}{c}80,85 \\
(38)\end{array}$ & \begin{tabular}{|c|}
82,98 \\
$(39)$
\end{tabular} & \begin{tabular}{|c|}
81,48 \\
$(22)$
\end{tabular} & $\begin{array}{c}23,81 \\
(5)\end{array}$ \\
\hline $\mathrm{Hi}$ & $\begin{array}{c}87,80 \\
(36) \\
\end{array}$ & $\begin{array}{c}39,22 \\
(20)\end{array}$ & \begin{tabular}{|c|}
38,46 \\
$(20)$
\end{tabular} & \begin{tabular}{|c|}
40,91 \\
$(18)$
\end{tabular} & \begin{tabular}{|c|}
86,84 \\
$(33)$ \\
\end{tabular} & \begin{tabular}{|c|}
31,58 \\
$(18)$ \\
\end{tabular} & \begin{tabular}{|c|}
28,07 \\
$(16)$ \\
\end{tabular} & $\begin{array}{c}29,27 \\
(12)\end{array}$ & $\begin{array}{c}80,65 \\
(25) \\
\end{array}$ & $\begin{array}{c}19,15 \\
(9)\end{array}$ & \begin{tabular}{|c|}
17,02 \\
$(8)$
\end{tabular} & \begin{tabular}{|c|}
18,52 \\
$(5)$
\end{tabular} & $\begin{array}{c}76,19 \\
(16)\end{array}$ \\
\hline \multicolumn{14}{|c|}{ Якість сну } \\
\hline \multicolumn{14}{|l|}{ Звичний час засинання } \\
\hline до 22 & $\begin{array}{c}17,46 \\
(11)\end{array}$ & 0 & 0 & 0 & $\begin{array}{c}11,32 \\
(6)\end{array}$ & 0 & 0 & 0 & $\begin{array}{c}7,32 \\
(3)\end{array}$ & 0 & 0 & 0 & $\begin{array}{c}7,41 \\
(2)\end{array}$ \\
\hline $22-00$ & $\begin{array}{c}74,60 \\
(47)\end{array}$ & $\begin{array}{c}83,33 \\
(50)\end{array}$ & $\begin{array}{c}80,00 \\
(48)\end{array}$ & $\begin{array}{c}86,79 \\
(46)\end{array}$ & $\begin{array}{c}88,68 \\
(47)\end{array}$ & \begin{tabular}{|c|}
80,70 \\
$(46)$
\end{tabular} & $\begin{array}{c}82,46 \\
(47)\end{array}$ & $\begin{array}{c}82,93 \\
(34)\end{array}$ & $\begin{array}{c}92,68 \\
(38)\end{array}$ & $\begin{array}{c}68,09 \\
(32)\end{array}$ & $\begin{array}{c}65,96 \\
(31)\end{array}$ & $\begin{array}{c}66,67 \\
(18)\end{array}$ & $\begin{array}{c}92,59 \\
(25)\end{array}$ \\
\hline після 00 & $\begin{array}{l}7,94 \\
(5)\end{array}$ & $\begin{array}{c}16,67 \\
(10)\end{array}$ & $\begin{array}{c}20,00 \\
(12)\end{array}$ & $\begin{array}{c}15,09 \\
(8)\end{array}$ & 0 & $\begin{array}{c}19,30 \\
(11)\end{array}$ & $\begin{array}{c}17,54 \\
(10)\end{array}$ & $\begin{array}{c}17,07 \\
(7)\end{array}$ & 0 & $\begin{array}{c}31,91 \\
(15)\end{array}$ & $\begin{array}{c}34,04 \\
(16)\end{array}$ & $\begin{array}{c}33,33 \\
(9)\end{array}$ & 0 \\
\hline \multicolumn{14}{|l|}{$\begin{array}{l}\text { Тривалість сну (загальна на } \\
\text { добу, включно з денним) }\end{array}$} \\
\hline менше 6 год & $\begin{array}{c}4,76 \\
(3)\end{array}$ & \begin{tabular}{|c|}
46,67 \\
$(28)$
\end{tabular} & \begin{tabular}{|c|}
45,00 \\
$(27)$
\end{tabular} & \begin{tabular}{|c|}
45,28 \\
$(24)$
\end{tabular} & $\begin{array}{c}18,87 \\
(10)\end{array}$ & \begin{tabular}{|c|}
50,88 \\
$(29)$
\end{tabular} & \begin{tabular}{|c|}
54,39 \\
$(31)$
\end{tabular} & \begin{tabular}{|c}
48,78 \\
$(20)$
\end{tabular} & \begin{tabular}{|c|}
17,07 \\
$(7)$
\end{tabular} & $\begin{array}{c}42,55 \\
(20)\end{array}$ & \begin{tabular}{|c}
44,68 \\
$(21)$
\end{tabular} & \begin{tabular}{|c|}
44,44 \\
$(12)$
\end{tabular} & $\begin{array}{c}7,41 \\
(2)\end{array}$ \\
\hline 6-9 год & $\begin{array}{c}88,89 \\
(56)\end{array}$ & $\begin{array}{c}46,67 \\
(28)\end{array}$ & $\begin{array}{c}48,33 \\
(29) \\
\end{array}$ & $\begin{array}{c}81,13 \\
(43)\end{array}$ & $\begin{array}{c}62,26 \\
(33) \\
\end{array}$ & $\begin{array}{c}38,60 \\
(22) \\
\end{array}$ & \begin{tabular}{|c|}
35,09 \\
$(20)$
\end{tabular} & $\begin{array}{c}41,46 \\
(17)\end{array}$ & \begin{tabular}{|c|}
82,93 \\
$(34)$
\end{tabular} & $\begin{array}{c}44,68 \\
(21)\end{array}$ & $\begin{array}{c}42,55 \\
(20) \\
\end{array}$ & $\begin{array}{c}44,44 \\
(12)\end{array}$ & $\begin{array}{c}92,59 \\
(25)\end{array}$ \\
\hline понад 9 год & $\begin{array}{c}6,35 \\
(4)\end{array}$ & $\begin{array}{c}6,67 \\
(4)\end{array}$ & $\begin{array}{c}6,67 \\
(4)\end{array}$ & $\begin{array}{c}7,55 \\
(4)\end{array}$ & 0 & $\begin{array}{c}10,53 \\
(6)\end{array}$ & $\begin{array}{c}10,53 \\
(6)\end{array}$ & $\begin{array}{c}9,76 \\
(4)\end{array}$ & 0 & $\begin{array}{c}12,77 \\
(6)\end{array}$ & $\begin{array}{c}12,77 \\
(6)\end{array}$ & $\begin{array}{c}11,11 \\
(3)\end{array}$ & 0 \\
\hline
\end{tabular}




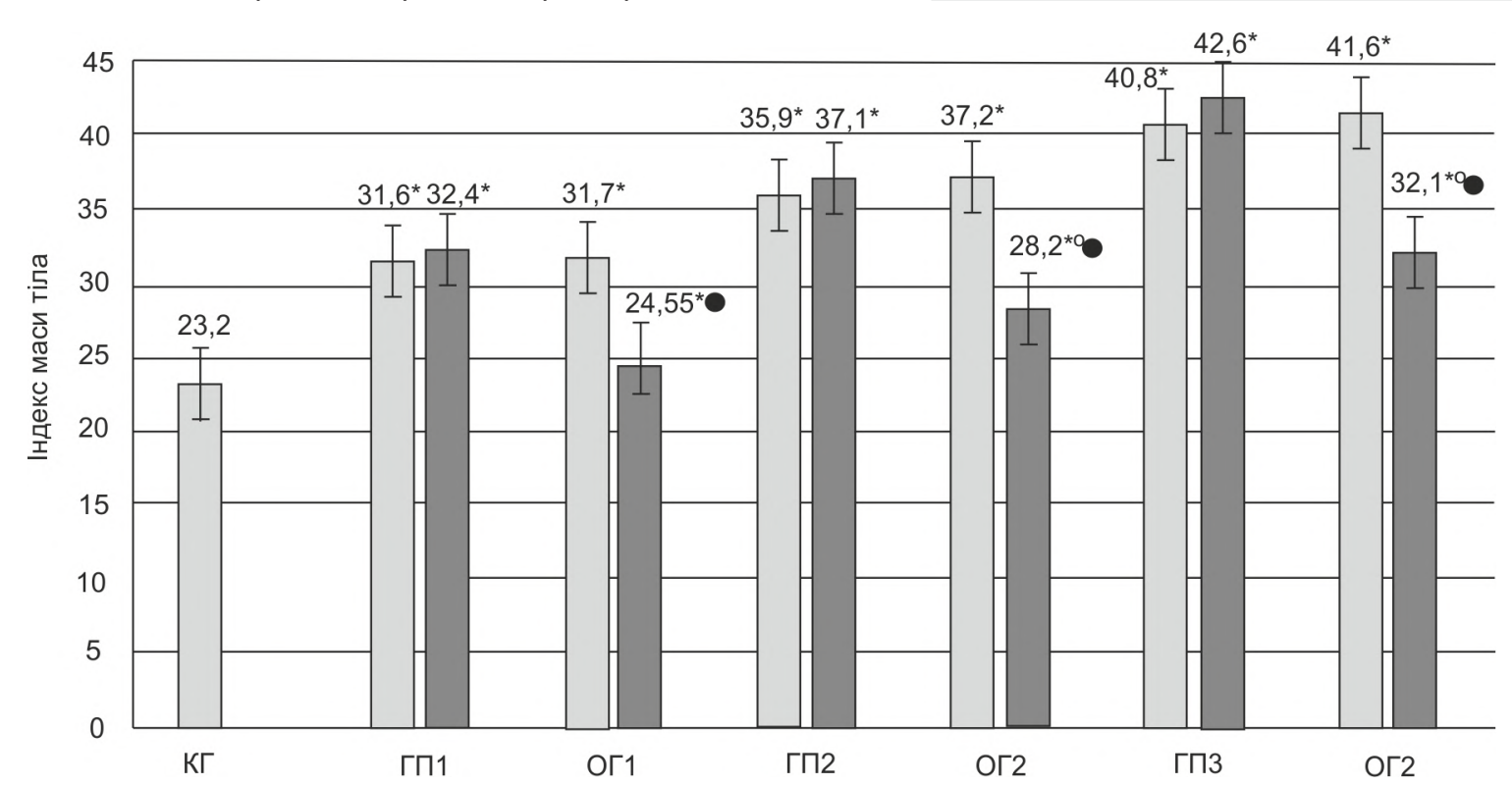

Рисунок 1 - Динаміка ІМТ під впливом розробленої програми ФТ (* - статистично значуща різниця порівняно із значенням відповідного показника КГ ( $<0,05) ;^{\circ}-$ статистично значуща різниця порівняно із показником первинного обстеження (для ГП) або відповідним показником до ФТ (для ОГ) (р < 0,05); - статистично значуща різниця порівняно із відповідним показником ГП (р < 0,05)): $\square$ - первинне обстеження; $\square-$ кінцеве обстеження

вони намагалися компенсувати додатковим вживанням продуктів («заїдання»).

Нестача нічного сну, що $€$ фрактором ризику АКО (внаслідок низької диференціації відчуттів втоми та голоду; бажання додати енергії не за рахунок відпочинку, а за рахунок споживання їі), також визначалась у більшості обстежених пацієнтів.

Поширеність модифрікованих фракторів ризику АКО за рахунок змін стилю життя визначалась тим частіше, чим більшим був ступінь ожиріння.

Якщо під час первинного обстеження на рівні ожиріння першого ступеня поширеність фракторів ризику в групах основній та порівняння була однаковою, то під час повторного обстеження виявлено провідну роль реабілітаційного комплаєнсу (згоди на виконання рекомендацій, наданих фрізичним терапевтом) у досягненні ефекту зниження маси тіла. Незважаючи на інфрормованість щодо шкідливого впливу АКО на стан здоров'я та принципи і засоби корекції маси тіла в рамках модифрікації стилю життя, у пацієнтів групи порівняння не визначено зменшення кількості факторів ризику, пов'язаних із нераціональним харчуванням, низькою руховою активністю, відчуттям стресу, нестачею сну (див. табл. 1).

Водночас у пацієнтів основної групи, які виконували рекомендовані заходи, за всіма запитаннями анкети визначалось значне зменшення поширеності фракторів ризику АКО. Це було об'єктивно підтверджено результатами кінцевого визначення IMT (рис. 1), що показало статистично значуще його зменшення відносно вихідних показників та покращення відносно відповідних параметрів ГП ( $p<0,05)$.

Проте, незважаючи на значне зменшення модифікованих фракторів ризику, в багатьох випадках, особливо при АКО третього ступеня, не визначалось їх повне нівелювання (очевидно, за рахунок звичних життєвих стереотипів, контекстуальних фракторів, недостатньо високого рівня комплаєнсу [6]), що є причиною неповної нормалізації маси тіла. Також це $є$ фрактором ризику її повторного рецидиву; при високих ступенях АКО потребує продовження реабілітаційних заходів під контролем фрізичного терапевта триваліше, ніж один рік. Для осіб з ожирінням першого ступеня, які нормалізували масу тіла, потрібним $€$ періодичний контроль з боку фрахівців для підтримання досягнутого ефекту.

Дискусія. Маса тіла - це сукупний результат раціону харчування та рухової активності впродовж усього життя, тому визначення в окремих випадках спожитих поживних речовин, видів їжі або загальних харчових звичок, без врахування інших довготривалих фракторів, - рухової активності, режиму дня, психоемоційного стану, тощо, - не завжди має відношення до розвитку АКО у віддаленому майбутньому. Люди можуть підтримувати енергетичний баланс на низькому або на високому рівні, але тільки в тому випадку, якщо споживання енергії ретельно регулю- 
ється відповідно до енергетичних потреб. Таким чином, щоб усвідомити детермінанти ожиріння, пов'язані з раціоном харчування, необхідно виявити ті фрактори (передусім аліментарні), які заважають організму досягти енергетичної рівноваги на тому чи іншому рівні витрат енергії [3, 5, 17, 20].

Визначити роль конкретного харчового продукту або поживної речовини важко через високу кореляцію між більшістю аліментарних фракторів і фракторами рухової активності та іншими особливостями способу життя. Повсякденний спосіб життя більшості людей - включаючи умови транспорту, проживання, професійної діяльності, навчання і дозвілля - все менше сприяє руховій активності і, отже, все сильніше - ожирінню.

Незалежно від причини, що спонукала хворого почати програму зі зниження маси тіла, важливо поставити реальні коротко- та довготермінові цілі реабілітації як щодо зниження маси тіла, так і щодо темпів іï̈ зниження. Лікування ожиріння довгий, часто довічний процес, а його основна мета - зменшення ризику розвитку супутніх ожирінню захворювань і збільшення тривалості життя, бажано одночасно зі зменшенням маси тіла.

Вважаємо, що під час корекції ожиріння доцільно поетапно вирішувати такі завдання: стабілізація маси тіла (при потребі пацієнта, це період, коли немає наростання IMT); зниження IMT на фоні модифрікації способу життя з метою зниження ризику розвитку ускладнень; по можливості, нормалізація маси тіла (важко досягається для хворих з морбідним ожирінням).

На сьогодні найбезпечнішою і разом з тим есрективною вважається методика поступового (0,5-1,0 кг на тиждень) зниження маси тіла впродовж 4-6 міс. і утримання результату протягом тривалого часу $[6,10,17]$. При цьому маса тіла втрачається переважно за рахунок жирової тканини, а не м'язової або кісткової. Такий темп зниження достатньо легко досягається та переноситься хворим, є безпечним, а ризик рецидиву - найменший. Досягнення цієї мети $є$ нереальним без активної участі пацієнта у щоденній модифікації стилю життя, що підтверджено у нашому дослідженні.

Модифікація рухової активності, нестача якої визначена за результатами тестування у всіх групах пацієнтів $з$ ожирінням, $€$ важливим компонентом терапії ожиріння, оскільки надає доведений ефект на довгострокове зниження маси тіла; відіграє важливу роль у запобіганні подальшого збільшення маси тіла, в тому числі й після корекції; позитивно впливає на здоров'я і якість життя пацієнта незалежно від його ваги. Для профрілактики ожиріння і гіподинамії, а також з метою зниження ризику серцево-судинних ускладнень дорослим необхідно принаймні 150 хв (2 год 30 хв) на тиждень аеробної рухової активності помірної інтенсивності або 75 хв (1 год 15 хв) у тиждень аеробної рухової активності високої інтенсивності [13, 17, 19]. Проведені нами попередні дослідження показали, що дотримання рекомендацій фрізичного терапевта дозволяє покращити показники якості життя пацієнтів з ожирінням, збільшити їх рухову активність та стан здоров'я [2, 14].

Обґрунтуванням елементів поведінкової терапії $€$ необхідність змін особливостей поведінки, які сприяють надмірному споживанню їжі, неправильному харчуванню, сидячому способу життя. Цілком доступною іiї частиною, яку може здійснювати фрізичний терапевт, $€$ детальна оцінка повсякденної діяльності пацієнта, визначення заходів, обставин і дій, які сприяють споживанню їжі, на основі чого розробляється індивідуальний план та визначаються реабілітаційні цілі для конкретного пацієнта $[9,12,20]$.

Особливу увагу слід звертати на якість сну пацієнта, що також показано у представленому дослідженні. Достатня тривалість сну позитивно впливає на жировий обмін, тоді як нестача сну обмежує здатність організму переробляти енергетичні ресурси і регулювати масу жирової тканини. Оптимальна тривалість сну для дорослої людини становить 7-8 год. Менша (< 6 год) або більша (> 9 год) тривалість сну підвищує ризик збільшення маси тіла [16].

Для попередження рецидиву слід рекомендувати пацієнтам уникати дієт для швидкого зниження маси тіла, оскільки вони призводять до розвитку патологічного циклу її коливань. В результаті цього має місце значуще більша маса тіла, ніж у пацієнтів без її коливань, впродовж наступних 4-6 років, а самі коливання $€$ фактором підвищеного ризику загальної і серцевосудинної смертності, ризику підвищення артеріального тиску у жінок і розвитку симптоматичної жовчно-кам'яної хвороби у чоловіків [7, 8].

Вважається, що обмеження калорійності, самоконтроль та навчання пацієнтів важливіші, ніж будь-який конкретний склад харчування, а навіть при подальшому наборі маси тіла позитивний ефрект зниження ваги на прозапальні маркери і біохімічні показники зберігається впродовж тривалого часу [11].

Проведене дослідження підтвердило важливість поступового та тривалого зменшення маси тіла. Оскільки фрізичний терапевт не має мож- 
ливості особисто відслідковувати життєдіяльність пацієнта, він його направляє, консультує, корегує та контролює. Основна мета та запорука успіху - зміна ставлення пацієнта до фракту наявності надлишкової маси тіла та бажання ії позбутися. Це, власне, і може бути досягнуто за допомогою фрахівців на фоні високого реабілітаційного комплаєнсу, а тривала самостійна свідома модифікація стилю життя $є$ запорукою успішності корекції маси тіла. Підвищення відповідальності пацієнта призводить до збільшення ступеня дотримання наданих рекомендацій, посилює самоконтроль, що особливо актуально в умовах тривалого зменшення маси тіла та пожиттєвого її утримання.

Пацієнти з низьким рівнем комплаєнсу щодо виконання немедикаментозних заходів стають потенційним контингентом для проведення оперативних баріатричних втручань та медикаментозного лікування.

\section{Висновки}

У хворих на ожиріння виявлено модифріковані етіологічні фрактори збільшення маси тіла: збільшення частоти прийомів їжі, харчування в другій половині дня, надмірне вживання тваринних

\section{Література}

1. Аравіцька М, Лазарєва О. Принципи створення та визначення ефективності системи заходів для подолання реабілітаційного нон-комплаєнсу пацієнтів з ожирінням [Principles of creating and determining the effectiveness of a system of measures to overcome the rehabilitation noncompliance of obese patients]. Спортивна медицина і фізична реабілітація. 2019;2:51-8. Доступно на: http://nbuv.gov.ua/UJRN/smed_2017_1_12. DOl: https://doi.org/10.32652/spmed.2019.2.51-58

2. Аравіцька М, Лазарєва О. Динаміка якості життя хворих з ожирінням під впливом програми фізичної реабілітації [Dynamics of the quality of life of obese patients under the influence of physical rehabilitation program]. Спортивна медицина і фізична реабілітація. 2017;1:72-8. Доступно на: http://nbuv.gov.ua/UJRN/smed_2017_1_12.

3. Старостина Е. Ожирение как психосоматическое заболевание [Obesity as a psychosomatic disease]. Ожирение и метаболизм. 2005;3:18-23. Доступно на: https://cyberleninka.ru/article/n/ozhirenie-kakpsihosomaticheskoe-zabolevanie

4. Паффренбаргер Р, Ольсен Э. Здоровый образ жизни [Healthy lifestyle]. Київ: Олімпійська література; 2002. 320 с.

5. Седлецкий Ю. Современные методы лечения ожирения. Руководство для врачей [Modern methods of treating obesity. A guide for doctors]. Санкт-Петербург: Элби-СПб; 2007. 415 c.

6. Adherence to Long-Term Therapies: Evidence for Action. New-York, WHO. 2003. Available from: http://whqlibdoc.who.int/publications/2003/ 9241545992.pdf.

7. Amundson D, Djurkovic S, Matwiyoff G. The obesity paradox. Critical Care Clinics. 2010;26(4):583-96. DOI: 10.1016/j.ccc.2010.06.004. (2010)

8. Batrakoulis A, Fatouros GI, Chatzinikolaou A, Draganidis D, Georgakouli K, Papanikolaou K, et al. Dose-response effects of high-intensity interval neuromuscular exercise training on weight loss, performance, health and quality of life in inactive obese adults: Study rationale, design and methods of the DolT trial. Contemporary clinical trials communications. 2019;15:100386. DOI: $10.1016 / j . c o n c t c .2019 .100386$ жирів, солі та солодощів, недостатнє вживання овочів та фрруктів, часте вживання фраст-фруду, а також недостатню рухову активність, стресові ситуації, порушення режиму та тривалості сну. Частота виявлених ризиків пропорційна ступеню ожиріння.

Низький рівень реабілітаційного комплаєнсу супроводжується невиконанням рекомендацій щодо модифікації стилю життя та, як наслідок, відсутності позитивної динаміки зменшення маси тіла.

Високий рівень комплаєнсу сприяє тривалій модифікації стилю життя хворих ожирінням, виконанню наданих рекомендацій i, як наслідок, значному зменшенню маси тіла.

Довготривала реабілітаційна стратегія схуднення повинна включати контролюючі заходи навіть після досягнення цільового рівня маси тіла.

Перспективи подальшого дослідження полягають у визначенні віддалених результатів розробленої програми ФТ для хворих на ожиріння у вигляді дотримання наданих рекомендацій, збереження досягнутої маси тіла або її зменшення.

Конфлікт інтересів. Автори заявляють про відсутність конфрлікту інтересів.

9. Bjorntorp P. Do stress reactions cause abdominal obesity and comorbidities? Obesity Reviews. 2001;2:73-86. DOI: 10.1046/j.1467789x.2001.00027.x

10. Cefalu WT, Bray GA, Home PD, Garvey WT, Klein S, Pi-Sunyer FX et al. Advances in the Science, Treatment, and Prevention of the Disease of Obesity: Reflections From a Diabetes Care Editors' Expert Forum. Diabetes Care. 2015;38(8):1567-82. DOI: 10.2337/dc15-1081

11. Cesa GL, Manzoni GM, Bacchetta M, Castelnuovo G, Conti S Gaggioli A, et al. Virtual reality for enhancing the cognitive behavioral treatment of obesity with binge eating disorder: randomized controlled study with oneyear follow-up. Journal of medical Internet research. 2013;15(6):113. DOI 10.2196/jmir.2441.

12. Doll HA, Petersen SE, Stewart-Brown SL. Obesity and physical and emotional well-being: associations between body mass index, chronic illness, and the physical and mental components of the SF-36 questionnaire. Obesity Research. 2000;8:160-70. DOI: 10.1038/oby.2000.17

13. Hainer V, Toplak H, Stich V.. Fat or Fit: What Is More Important? Diabetes Care. 2009;32(2):392-7. DOI: 10.2337/dc09-S346

14. Lazareva O, Aravitska M, Andrieieva O, Galan Y, Dotsyuk L. Dynamics of physical activity status in patients with grade I-III obesity in response to a physical rehabilitation program. Journal of Physical Education and Sport. 2017;17(3):1960-5. DOI: 10.7752/jpes.2017.03193

15. Mozaffarian D, Hao T, Rimm EB, Willett WC, Hu FB. Changes in diet and lifestyle and long-term weight gain in women and men. New England Journal of Medicine. 2011;364 (25):2392-404. DOI: 10.1056/NEJMoa1014296

16. Nedeltcheva AV, Kilkus JM, Imperial J, Schoeller DA, Penev PD. Insufficient sleep undermines dietary efforts to reduce adiposity. Annals of Internal Medicine. 2010;Oct;153(7):435-41. DOI: 10.7326/0003-4819-153-7201010050-00006

17. Patnode CD, Evans CV, Senger CA, Redmond N, Lin JS. Behavioral Counseling to Promote a Healthful Diet and Physical Activity for Cardiovascular Disease Prevention in Adults Without Known Cardiovascular Disease Risk 
Factors: Updated Systematic Review for the U.S. Preventive Services Task Force [Internet]. Rockville (MD): Agency for Healthcare Research and Quality (US). 2017; Jul. Report No.: 15-05222-EF-1. Availible at: https://www.ncbi.nlm. nih.gov/books/NBK43437/

18. Peeters A, Barendregt JJ, Willekens F, Mackenbach JP, Al Mamun A, Bonneux L. Obesity in adulthood and its consequences for life expectancy: a life-table analysis. Annals of Internal Medicine. 2003;138(1):24-32. DOI: 10.7326/0003-4819-138-1-200301070-00008

aravmedic@gmail.com
19. World Health Organization. Obesity: preventing and managing the global epidemic. Report of a WHO Consultation (WHO Technical Report Series 894). Available from: http://www.who.int/nutrition/publications/obesity/WHO_ TRS_894/en

20. Zimmerman GL, Olsen CG, Bosworth MF. A 'stages of change' approach to helping patients change behavior. American family physician 2000;61(5):1409-16. 